\title{
Initial colonisation by Rhizocarpon geographicum in the Tatra Mountains
}

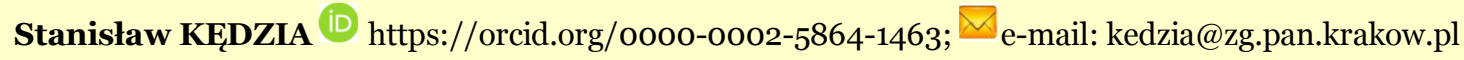 \\ Department of Geoenvironmental Research, Institute of Geography and Spatial Organization, Polish Academy of Sciences, \\ Cracow 31-018, ul. św. Jana 22, Poland
}

Citation: Kędzia S (2021) Initial colonisation by Rhizocarpon geographicum in the Tatra Mountains. Journal of Mountain Science 18(2). https://doi.org/10.1007/s11629-020-6130-3

(C) The Author(s) 2021.

\begin{abstract}
Previous lichenometric dating of young geomorphological forms in the Tatra Mountains has been hindered by differences in the determination of initial colonisation of fresh rock surfaces by the Rhizocarpon geographicum lichen. In order to determine precisely the time needed for the first thalli to appear on newly exposed rock surfaces, two experimental sites were created in 2013. The results from these sites were compared with the measurements taken on boulders in debris formed by a 2013 debris flow. In 2018, the largest thalli measured within the experimental sites and the debris flow area reached a size of approximately $2 \mathrm{~mm}$. Based on this, the time of initial colonisation of rock surfaces was determined to be $5 \pm 1$ years, which is about half the period previously described in the literature.
\end{abstract}

Keywords: Lichenometric dating; Rhizocarpon geographicum; Initial colonisation; Geomorphological forms; Tatra Mts

\section{Introduction}

Lichenometric dating has been used in geographic and geological sciences for about six decades (i.a. Beschel 1961, 1973, Armstrong 1976, 1978, 1983, 2002, 2015, Karlén 1973, Webber and Andrews 1973, Matthews 1974, Topham 1976, Armstrong and Smith 1987, Benedict 1991, 2009,

Received: 07-Apr-2020

1st Revision: 21-Jul-2020

$2^{\text {nd }}$ Revision: 11-Sep-2020

Accepted: 15-Oct-2020
Innes 1982, 1983, 1988, Bradwell 2009). However, some scientists question almost completely the lichenometric dating method (Osborn et al. 2015). Some of the objections should be considered correct in relation to forms (eg glacial moraines) formed over a long period of time and material of different ages. In the case of dating geomorphological forms formed in a short time (rock falls, debris flow), most of the accusations are incorrect. Among geographers, the most frequent users of such dating techniques are geomorphologists. Thanks to lichenometric dating, it is possible to establish the relative age of various events (e.g. rock falls, debris flows, thrust faults, and stagnation of glacier tongues), and estimate the intensity of these processes (Decaulne et al. 2005). Lichenometric dating requires the construction of the thallus growth curve for the study area. Lichen thalli colonise freshly exposed rock surfaces at different times depending mainly on the climate. In polar climates, the thalli of rock lichens from the Rhizocarpon group need as many as several dozen years to colonise a rock surface, while in moderate climates initial colonisation times range from several years to more than ten years (i.a. Armstrong 1981, Calkin et al. 1998, Armstrong and Bradwell 2001, Winchester and Chaujer 2002, Solomina and Calkin 2003, Larocque and Smith 2004, Forman et al. 2007, Benedict 2008, Hansen 2010, Gupta et al. 2014.).

Generally, as the age of lichenometrically dated geomorphological forms increases, the accuracy of their dating decreases. In the Tatra and Karkonosze Mountains, the thalli of lichens from the Rhizocarpon 
group which are older than 200 years and meet the conditions of this dating method are rare (Kotarba 1989, 1991, Kędzia 2013, Kędzia and Parzóch 2013, 2016). When determining the age of forms that are 150-200 years old, dating accuracy of \pm 10 years should be considered as very high and is not often achievable. However, when dating young forms aged 10-20 years, the above accuracy is unacceptable. In order to achieve a dating accuracy of 2-4 years for very young geomorphological forms, it is necessary to resolve the issue of the initial colonisation of newly exposed rock surfaces by lichens. Without specifying this, the dating of young geomorphological forms is very difficult.

A ruler or electronic callipers are the most important instruments for measuring the thalli of rock lichens. When measuring very small thalli, use can be made of a magnifier, which is helpful in identifying the lichen species and size. For an average geographer equipped with the above measuring equipment, thalli with a diameter of approx. 1.5-2.0 $\mathrm{mm}$ can be considered as measurable. Therefore, initial colonisation should be defined as the period between the occurrence of an event and the appearance of the earliest thalli with the above diameter. A. Kotarba, who first established the thallus growth curve for the northern slope of the Tatra Mountains in 1988, estimated that the thus defined initial colonisation for the 'very cold zone' (1550-1850 m a.s.l.) was about 12 years (Kotarba 1988, Jonasson et al. 1991). In 2013, S. Kędzia determined the lichenometric curve for the Tatra Mountains with a new method and estimated initial colonisation at 9-10 years (Kędzia 2013, 2015b). The discrepancy between these two authors is small, but they determined initial colonisation on the basis of thalli, the youngest of which were more than 20 years old. Meanwhile, the most accurate results are obtained by measuring thalli on fresh rock surfaces on a year-by-year basis. Therefore, the purpose of the research described in this paper is to determine initial colonisation of fresh rock surfaces by Rhizocarpon geographicum. In order to determine the rate of colonisation of fresh rock surfaces, two experimental sites were set up in 2013 on which fresh rock surfaces were observed to record the appearance of thalli each year. The results of measurements from these two plots were compared with the results obtained from measurements of rock surfaces from a 2013 debris flow.

\section{Materials and Methods}

\subsection{Study area}

The research was conducted in the Polish part of the Tatra Mountains in the Sucha Woda and Rybi Potok Valleys (Fig. 1). Two experimental plots were laid out in the Sucha Woda Valley. One of them was created next to the fence of the meteorological garden of the Hala Gąsienicowa weather station at an altitude of $1520 \mathrm{~m}$ (Fig. 2). The station is situated on the slope of a valley with eastern exposure. Three granite boulders with no thalli were obtained from moraine formations. These were washed in water from a local

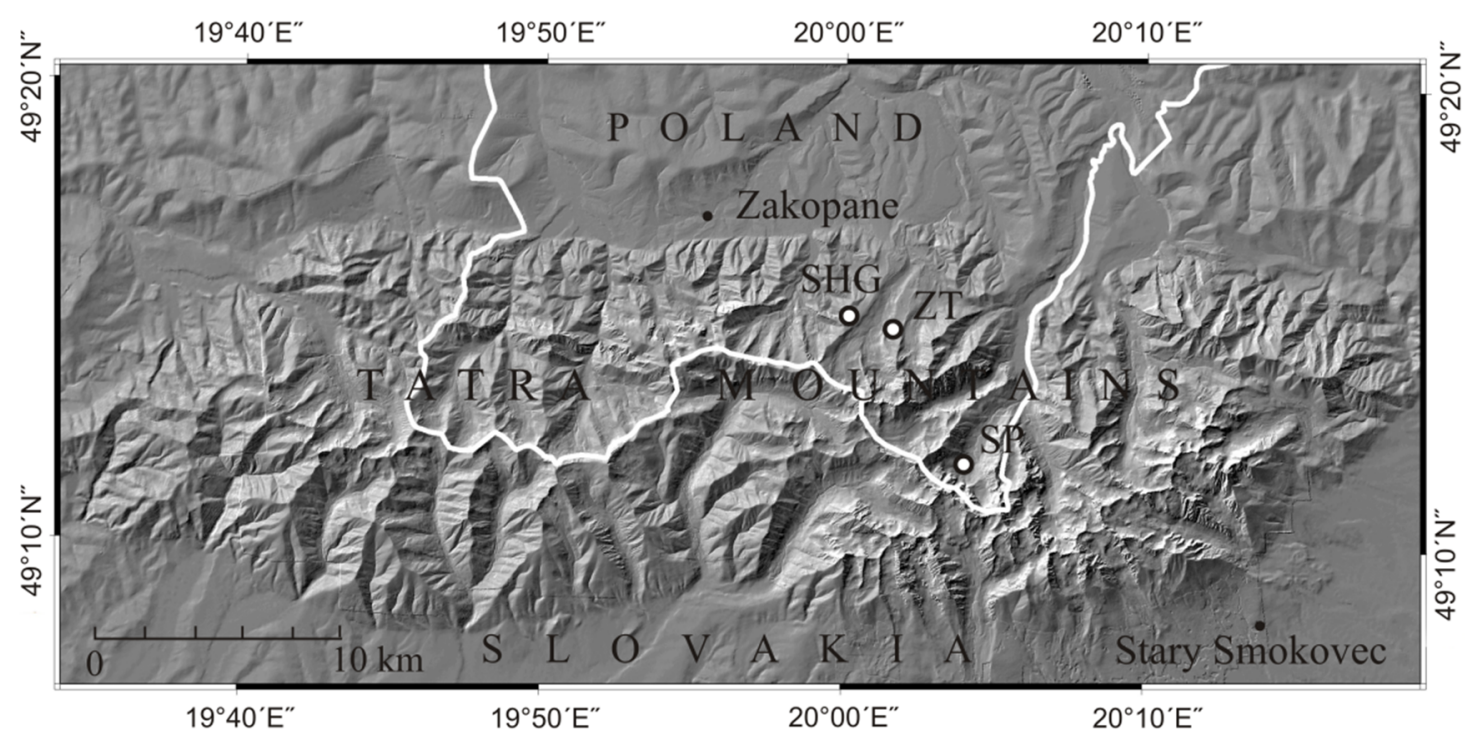

Fig. 1 Map of the Tatra Mountains including the research sites. SHG - Hala Gąsienicowa Station, ZT - Żółta Turnia, SP - Szeroki Piarg, white line - state border. 
stream and scrubbed with rock crumbs. The boulders were placed on high-mountain grassland (Fig. 3). The site reflects the conditions in which boulders deposited within landforms created by debris flows have been exposed and moved to another location by another debris flow.

The second site was located at an altitude of about $1635 \mathrm{~m}$, next to the tongue of a debris flow on the western, rocky slope of Żólta Turnia (Fig. 4). In contrast to the first site, the boulders here were taken from rock debris and split into two or three parts (3 boulders split into 7 parts -8 measuring surfaces). The broken boulders were placed between old boulders covered with thalli (Fig. 5). Observation of the colonisation rate was carried out on the fresh surfaces formed by the boulder splitting. Additionally, on one boulder, observations were made on an old lateral surface which had been free of thalli on account of it having previously adhered to another boulder. This site reflects the conditions of rock

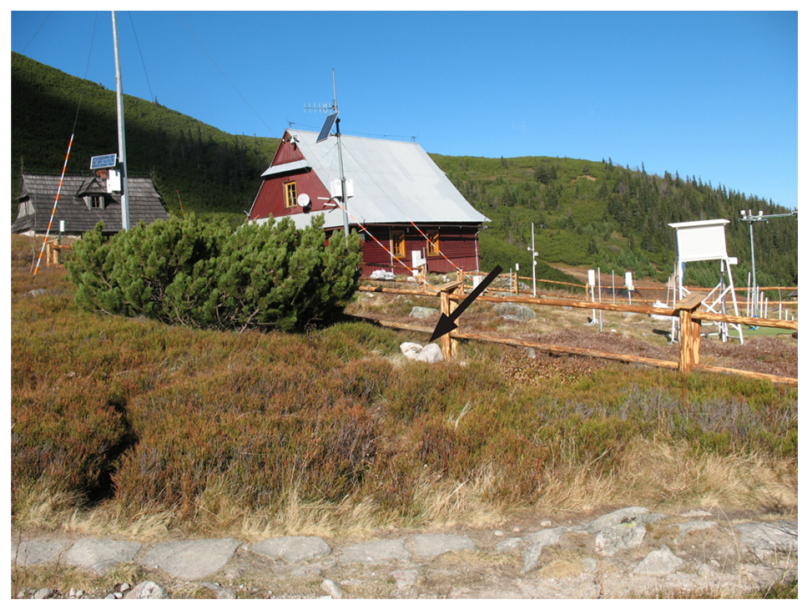

Fig. 2 The Hala Gąsienicowa Station site. The arrow points to the boulders where thalli were measured.

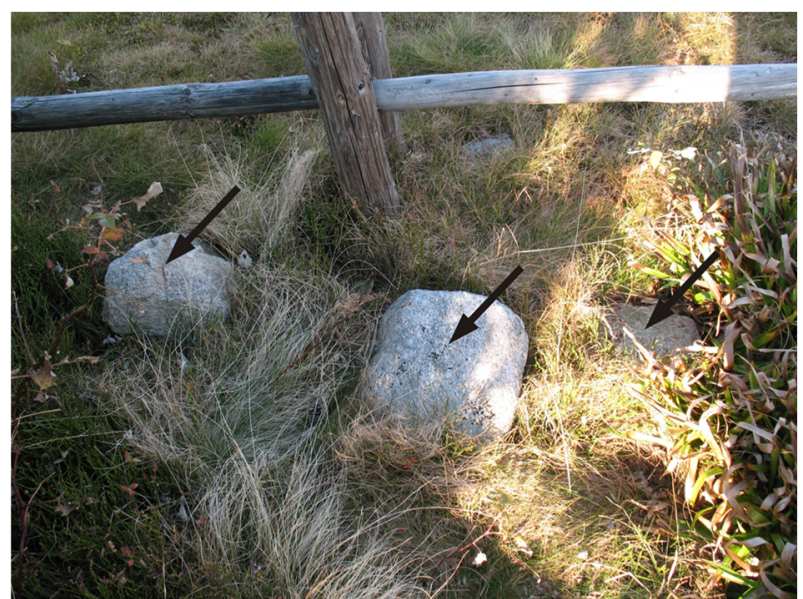

Fig. 3 Boulders on the Hala Gąsienicowa Station site. material detached from a rock wall.

The third site was established in the Rybi Potok Valley on the Szeroki Piarg scree, which is part of the Great Piarg scree on Morskie Oko Lake at the foot of a rock wall (Fig. 6). The scree has a northern exposure. The thalli were measured on 9 boulders located at an altitude of about 1480-1510 m, which had been taken from a 2013 debris flow (Fig. 7).

All the boulders investigated were granite. The difference in altitude between the lowest and the highest sites was about $135 \mathrm{~m}$. The average annual temperature at this height is about $2.0^{\circ} \mathrm{C}$, while the average annual rainfall is about $1650 \mathrm{~mm}$. Obviously, there are slight differences between the study sites as regards the average annual air temperature, which are attributable to the differences in altitude, exposure and proximity to lakes. The snow cover lasts for an average of about 7 months (Hess 1965, Koňcek and Orlicz 1974, Błażejczyk et al. 2013). The snow lasts the longest on the Szeroki Piarg scree (up to about 8

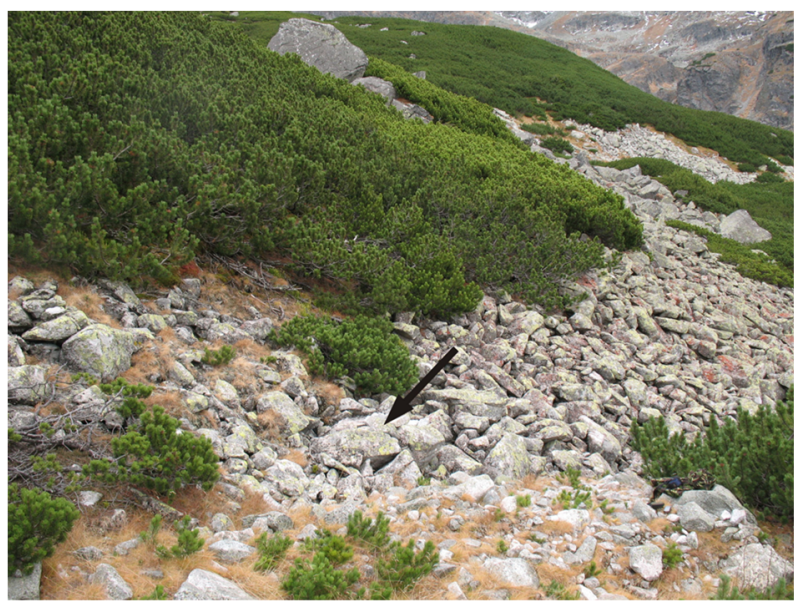

Fig. 4 The Żółta Turnia site.

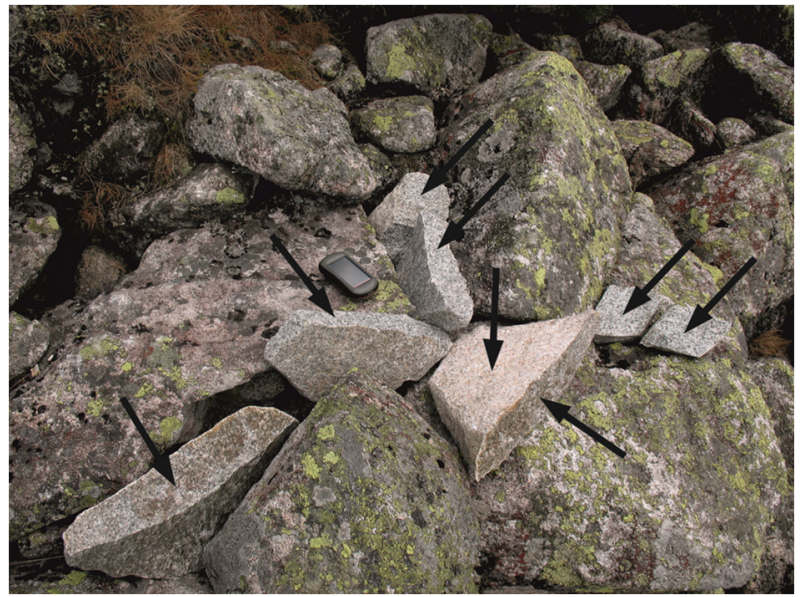

Fig. 5 Boulder surfaces measured on the Żółta Turnia site. 
months), and the shortest next to the Hala Gąsienicowa weather station (about 6 months). The long-lasting snow cover on the Szeroki Piarg scree is not only caused by the northern exposure and heavy shading, but also by snow avalanches.

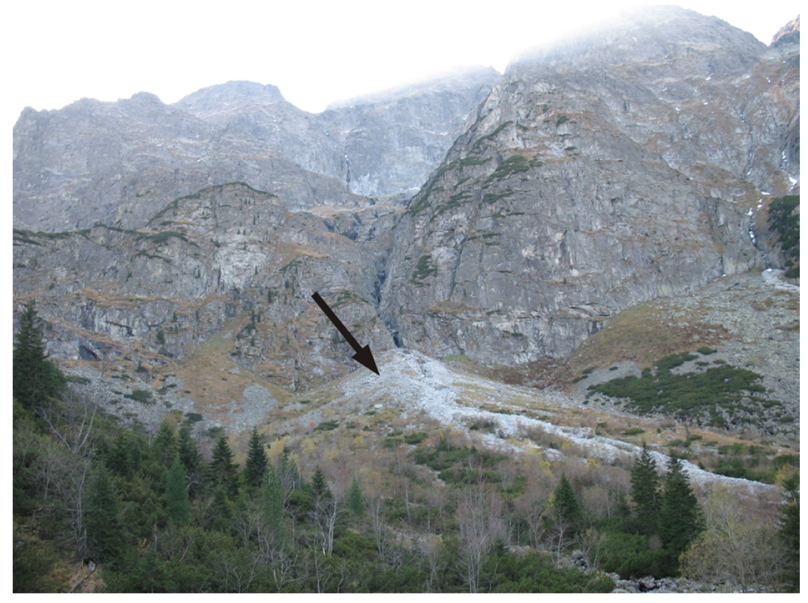

Fig. 6 The Szeroki Piarg site.

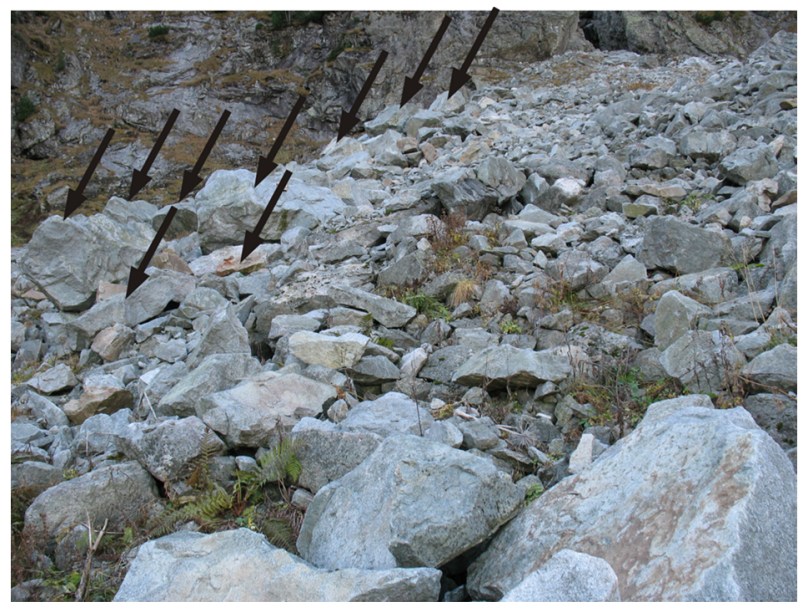

Fig. 7 Boulders in the debris flow on the Szeroki Piarg site where thalli were measured.

\subsection{Research methods}

The measurements were carried out using a transparent ruler and a magnifying glass with fourfold magnification. The thallus diameter measurement accuracy, taking into account the irregular shapes of the thalli, was about $\pm 0.3 \mathrm{~mm}$. In lichenometric dating, use is made of various methods of measuring thalli. The most common ones include measurement of the longest axis, the largest inscribed circle, or average value of the largest and smallest diameters (Innes 1984, 1985ab, Hansen 2008). Since all previous measurements of thalli in the Polish mountains have been conducted using the longest axis method, the method was also used in the present study. In accordance with the prevailing standard for the Tatra Mountains and the majority of mountains in Europe, measurements were made of the 5 thalli (5LL) with the largest diameter on each boulder (Kotarba 1989, 1991, 2001, 2004, Kędzia 2013, 2015a, b, Kędzia and Parzóch 2016). Altitude above sea level was determined on the basis of topographic maps and GPS Garmin Oregon 300 readings.

Observations were conducted every year at the Hala Gąsienicowa Station and Źółta Turnia sites. Some thalli were observed as early as 2016, but given their very small size and the associated difficulty in identifying the species of lichen and the low accuracy of standard measurements (ruler and magnifier), it was only in 2018, when the largest thalli were approx. $2 \mathrm{~mm}$ in diameter, that they were identified and measured. At the Szeroki Piarg and Morskie Oko sites, the thalli were measured once in 2018.

\section{Results}

The earliest thalli on the boulders at the Hala Gąsienicowa weather station appeared in small cavities on the surface. They had an irregular shape and their maximum diameter was about $2 \mathrm{~mm}$ in October 2018 (Table 1). The colonisation did not take place at the same time on all the surfaces. The earliest thalli appeared on the lateral surfaces of boulders shaded by high-mountain grass. The colonisation of rock surfaces takes place regardless of their exposure. Most thalli were identified on the lateral surfaces of the two largest boulders -8 in total (Table 1). Thalli were found both on their shaded and sun-exposed sides. No thalli were found on the lateral sides and the top surface of the smallest boulder. Thalli appeared latest on the upper surfaces of the two largest boulders - a total of 4 were counted. With a measurement accuracy of about $\pm 0.3 \mathrm{~mm}$ and thallus diameter of about $2 \mathrm{~mm}$, it is difficult to determine clearly how smaller thalli on the top surface of the boulders compare with those on the sides. Another measuring problem was posed by the irregular shapes of thalli. It can be assumed that the top thalli were 0.2-0.3 mm smaller. Only those thalli that were large enough for them to be identified were measured. This means that the actual number of Rhizocarpon geographicum lichen thalli was much greater. 
Table 1 Description of the measurement sites in the Sucha Woda and Rybi Potok Valleys.

\begin{tabular}{|c|c|c|c|c|c|c|}
\hline 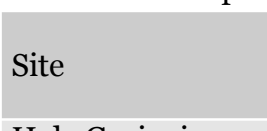 & $\begin{array}{l}\text { Altitude } \\
\text { [m a.s.l.] }\end{array}$ & $\begin{array}{l}\text { Exposure of } \\
\text { measurement } \\
\text { sites }\end{array}$ & $\begin{array}{l}\text { Quantity of } \\
\text { measured } \\
\text { thallus }\end{array}$ & $\begin{array}{l}\text { Diameters of the } 5 \\
\text { largest thallus [mm] }\end{array}$ & $\begin{array}{l}\text { The average diameter } \\
\text { of the } 5 \text { largest thallus } \\
{[\mathrm{mm}]}\end{array}$ & $\begin{array}{l}\text { Since } \\
\text { year* }\end{array}$ \\
\hline $\begin{array}{l}\text { Hala Gąsienicowa } \\
\text { Station }\end{array}$ & 1520 & 20. & 12 & $2.2 ; 2.2 ; 2.0 ; 1.8 ; 1.8$ & $\sim 2.0$ & 2013 \\
\hline Żółta Turnia & 1635 & $\mathrm{~W}$ & 17 & $2.2 ; 2.2 ; 2.2 ; 2.0 ; 2.0$ & $\sim 2.1$ & 2013 \\
\hline Szeroki Piarg & $1480-1510$ & $\mathrm{~N}$ & 27 & $2.2 ; 2.0 ; 2.0 ; 2.0 ; 2.0$ & $\sim 2.0$ & 2013 \\
\hline
\end{tabular}

Note: Since year*, the year of the surface exposure.

At the Żólta Turnia site, the colonisation of the fresh rock surfaces created by the splitting of the boulders mainly started from the edges of these surfaces (Figs. 8, 9). It appeared as though thalli from the old, previously colonised lateral surfaces started to spread towards the fresh rock surfaces. The more thalli that were seen on the old lateral surfaces, the more new thalli were noted on the fresh surfaces at the edges adjacent to the old surfaces. In the central areas of fresh rock surfaces, the number of visible thalli was low (Fig. 10). It could be observed that, likewise, colonisation on the old lateral thalli-free surfaces was progressing predominantly from the edge. The young thalli, as on the site at the Hala Gąsienicowa weather station, had irregular shapes, and their largest diameter was about $2 \mathrm{~mm}$. Thalli were not found on all the surfaces. Most probably, some of the surfaces surveyed had thalli that were too small for them to be noticeable, or the surfaces had not yet been colonised. A total of 17 thalli on 4 rock surfaces were measured. Twelve of them were located on 3 surfaces formed by boulder split, and 5 were measured on old surfaces that had not previously been overgrown with thalli (Table 1).

In order to compare the results from the experimental sites with natural processes, measurements were made of thalli on boulders from the 2013 debris flow on the Szeroki Piarg scree in the Rybi Potok Valley. These measurements were made on fresh rock surfaces. As on the Żólta Turnia and Hala Gąsienicowa site, no thalli were found on some surfaces, while those that were actually identified and measured were mostly irregular in shape. Their maximum diameter reached about $2 \mathrm{~mm}$ and they were often found in small cavities on the rock surfaces. Unfortunately, old, weathered surfaces lacking thalli were not identified. Out of 9 boulders, only 4 had thalli that were large enough to be identified and measured. A total of 27 thalli were measured.

To sum up, for the 1450-1650 m altitude range, it can be assumed that the minimum time in which the largest thalli reach approx. $2 \mathrm{~mm}$, allowing them to be

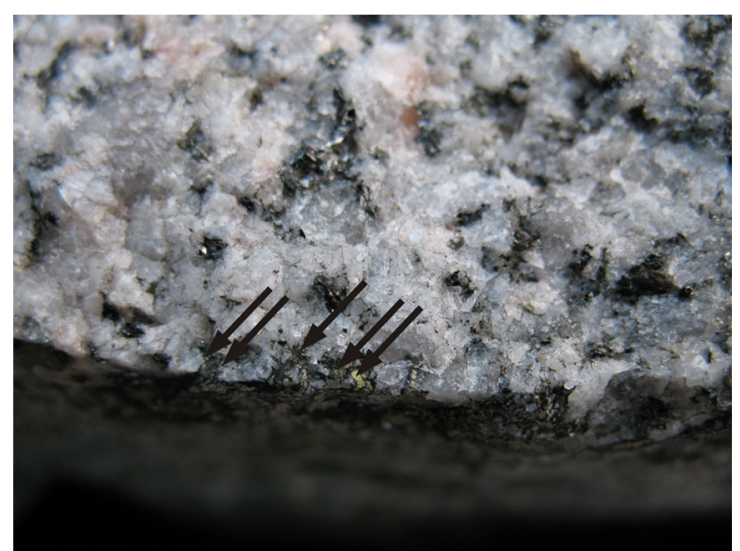

Fig. 8 Five young thalli on one of the boulders at the Źółta Turnia site (2018).

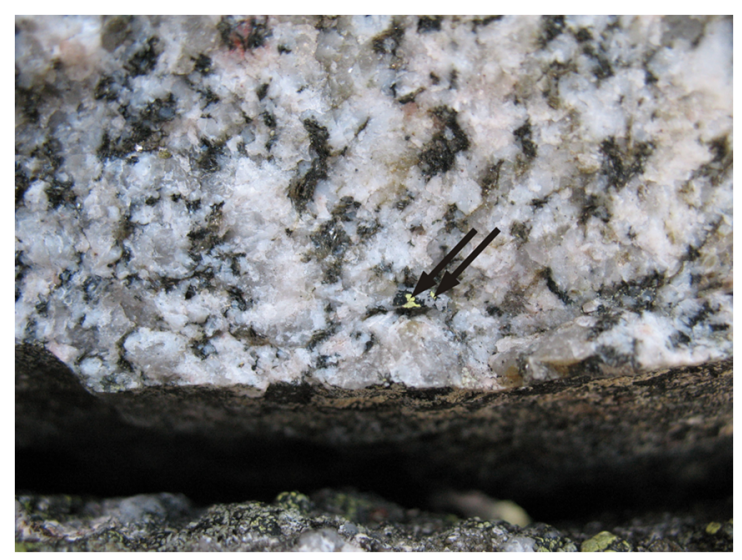

Fig. 9 Two young thalli on one of the boulders at the Żółta Turnia site (2018).

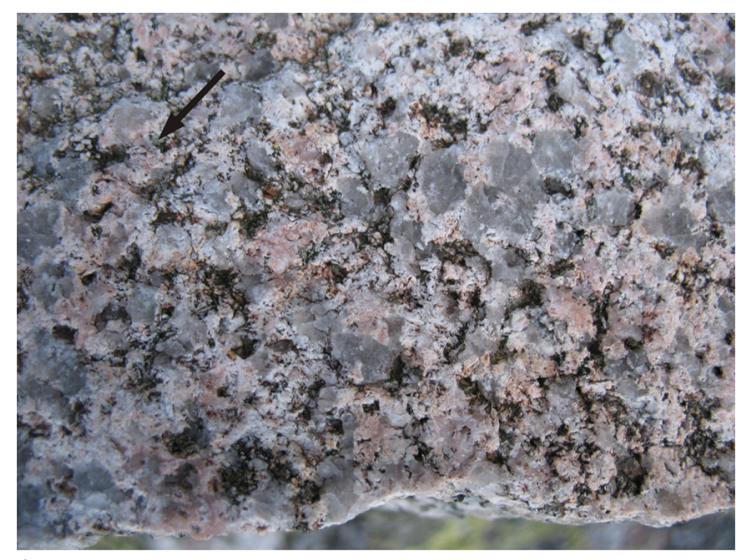

Fig. 10 Young thalli on one of the boulders at the Źółta Turnia site (2018). 
identified and measured with a ruler and magnifying glass, is $5 \pm 1$ years. Several years earlier, S. Kędzia and K. Parzóch obtained a similar result in the Karkonosze Mountains (Kędzia and Parzóch 2016). The result is also similar to the results obtained in many other European mountain ranges (Armstrong 1981, Evans and Archer 1999, Pech et al. 2003, Larocque and Smith 2004; Solomina et al. 2010, Bradwell 2010). It is about half as long as the period for initial colonisation previously assumed for the Tatra Mountains (Fig. 11).

\section{Discussion}

At the Hala Gąsienicowa site, thalli appeared earliest on the lateral boulder surfaces, regardless of the exposure, and grew latest on top of the rocks, which proves that increased moisture on the sides of the boulders was the key factor behind the development of thalli (Armstrong 2005, 2006, 2016, Armstrong and Bradwell 2010a, b, 2015, Trenbirth and Matthews 2010). From the moment the snow cover disappears in spring to its re-emergence in autumn, tall mountain grass grows around the boulders, causing dewdrops and raindrops to persist longer than on the top of the boulders. By contrast, the upper surfaces of the boulders are characterised by the greatest insolation and the lowest humidity, which most likely delays their colonisation. It is difficult to say why no thalli large enough to be identified grew on the last and smallest of the boulders. Most probably, this was mainly caused by the grass that adhered to the sides and partly also to the top surface of the boulder in the warm period of the year.

There was no grass at the Żólta Turnia site. The boulders used in the measurements were situated on the top of other, older boulders. Almost all the surfaces on which thalli were measured faced upwards. New thalli appeared first in areas adjacent to edges with old thalli. At this site, the key role in the colonisation was played by old thalli-covered boulder surfaces because it was there that the colonisation of fresh rock surfaces began. No thalli large enough to be identified and measured were found on four of the surfaces included in the measurements, with the underlying reason being difficult to establish clearly. Although the snow cover at this site lasts about 1 month longer than at the Hala Gąsienicowa site and although the site lies about $100 \mathrm{~m}$ higher, the thalli had a similar size as at the latter location. The only reasonable explanation is the proximity of a large mountain lake, namely Czarny Staw. The Żółta Turnia site was situated about 30 metres from the shore of this lake, which, according to research conducted by Armstrong and other researchers, could have accelerated the thallus growth rate.

The greatest number of measurable thalli was found at the Szeroki Piarg site, which was clearly attributable to the large number of boulders that were measured and the large measuring surfaces. This site differed from the other ones by the greatest degree of shading and the longest lasting snow cover. Because snow lies at this site for about 2 months longer than at Hala Gąsienicowa, thalli should appear here the last. However, they appeared at about the same time as in the two sites mentioned above, which was certainly due to the size of the boulders. At the previously discussed sites, the rocks were small, with their height

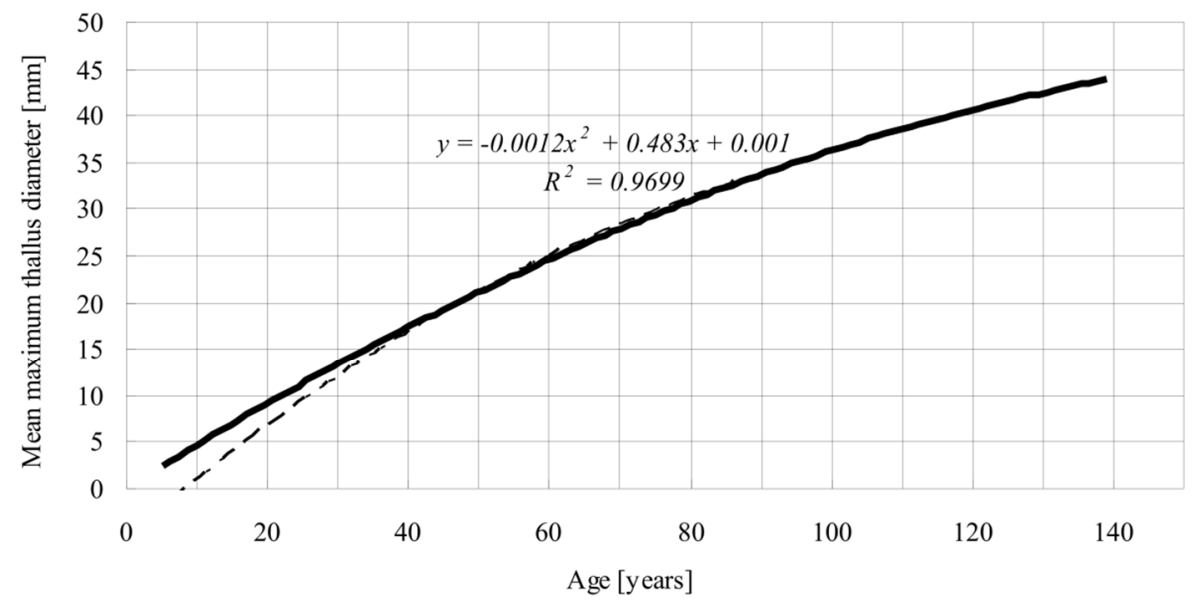

Fig. 11 Modified growth curve of Rhizocarpon geographicum thalli for the northern slope of the Tatra Mountains. Solid line - new curve, dashed line - old curve (Kędzia 2015b - changed). 
not exceeding $30 \mathrm{~cm}$. By contrast, at the Szeroki Piarg site, the largest boulders were about $1.5 \mathrm{~m}$ in height. As a result, despite the thick snow cover, the top surfaces of the boulders emerged from under the snow faster than the smaller rocks at the two previous sites, which was reflected in the colonisation of thalli. Nearly all the thalli were measured on the upper parts of the boulders. Perhaps the pace of colonisation was also influenced by the substantial shading of this measuring site by steep rock walls and the large mountain lake more than $100 \mathrm{~m}$ distant - Morskie Oko (Trenbirth and Matthews 2010). It is also noteworthy that no thalli were found on over half of the boulders. There were either no thalli at all or they were too small to be identified.

As mentioned earlier, the colonisation time is relevant only when young geomorphological forms are dated. With older forms, a difference in colonisation time of several years can be considered negligible. In addition, the climate changes that have taken place in the Tatras since the end of the Little Ice Age have most probably not affected the colonisation of rock surfaces by thalli, and thus the dating of old geomorphological forms. According to research by S. Kędzia, the number of days with snow cover has decreased by only about 10 over the last 100 years.

The results of measurements between the specially created measuring sites Hala Gąsienicowa and Żólta Turnia are compatible both with each other and with the results obtained on the boulders of the debris flow in the Rybi Potok Valley. This proves that despite the high sensitivity of lichen to changes in the surrounding environment, the minimum time of initial colonisation of fresh rock surfaces for the individual altitude ranges can be considered more or less the same across the northern slope of the Tatra Mountains. Undoubtedly, this is due to the local conditions of the individual sites (proximity to lakes, size of boulders, tall grass). Contrary to what had been found, inter alia, by O. Solomina and P.E. Calkin (2003), Benedict (1990), Trenbirth and Matthews (2010), there were no measurable variations in initial colonisation depending on altitude, exposure, temperature, total precipitation and snow cover. As well as local conditions, the second and probably most important factor behind the uniform diameter of thalli at all three sites is measurement accuracy. With such small diameters of the thalli and short observation time, differences in the colonisation rate are smaller than the measurement error.
Unfortunately, measuring very small thalli is extremely difficult and burdened with a large error due to their largely non-circular shape. When use is made of a ruler and magnifying glass, the measurement accuracy is approximately $\pm 0.3 \mathrm{~mm}$. Therefore, when measuring a thallus of $1.5-2.0 \mathrm{~mm}$ in diameter, the measurement error can reach up to $20 \%$ of the measured value. This means that when measuring small thalli, the error in determining initial colonisation can be about 1 year. Most probably, further measurements of the size of thalli will demonstrate differences in the range of growth attributable to local conditions. However, at this stage of the research, they could not be clearly identified.

\section{Conclusion}

Not all rock surfaces are colonised by Rhizocarpon geographicum after the lapse of the same time period. On some surfaces, no thalli were identified. The fastest colonisation occurs on old, weathered and shady surfaces and on fresh surfaces at the borders with old thalli-covered surfaces. The earliest thalli usually appear in small cavities and small cracks in the rock surfaces.

Because the initial time determined by the present study is $5 \pm 1$ years and is half as long as previously assumed, the shape of the lichenometric curve used for dating has changed. Fig. 11 presents the modified shape of the thalli growth curve for the northern slope of the Tatra Mountains determined in the traditional way. The beginning of the curve is not in contact with the $\mathrm{Y}$-axis or the $\mathrm{X}$-axis, as opposed to the thallus growth curves for other mountain ranges, which usually come into contact with the $\mathrm{X}$-axis at values of several to a dozen or so, or even several dozen, years.

The initial colonisation determined refers to altitudes in the $1450-1650 \mathrm{~m}$ a.s.l. range. Thalli growing at other altitudes may demonstrate slightly different initial colonisation times. Therefore, the dating of objects that are significantly below or above the above altitude belt will have a slightly higher error than \pm 1 year.

The time of initial colonisation of fresh rock surfaces by Rhizocarpon geographicum thus identified will allow very young geomorphological forms to be dated in a more accurate way. 


\section{Acknowledgments}

The author would like to thank prof. Adam Kotarba (Polish Academy of Sciences) for constructive

Open Access This article is distributed under the terms of the Creative Commons Attribution 4.0 International License (http://creativecommons. org/licenses/by/4.0/), which permits unrestricted use, distribution, and reproduction in any medium,

\section{References}

Armstrong RA (1976) Studies on the growth rate of lichens. In: Brown DH, Hawksworth DL, Bailey RH (eds.), Progress and Problems in Lichenology. London: Academic Press. pp 309322.

Armstrong RA (1978) The colonization of a slate rock surface by a lichen. New Phytologist 81: 85-88.

Armstrong RA (1981) Field experiments on the dispersal, establishment and colonization of lichens on a slate rock surface. Environmental and Experimental Botany 21: 116-120.

Armstrong RA (1983) Growth curve of the lichen Rhizocarpon geographicum. New Phytologist 94: 619-622.

Armstrong RA (2002) The effect of rock surface aspekt on growth, size structure and competition in the lichen Rhizocarpon geographicum. Environmental and Experimental Botany 48: 187-194.

https://doi.org/10.1016/Soo98-8472(02)00040-0

Armstrong RA (2005) Radial Growth of Rhizocarpon Section Rhizocarpon Lichen Thalli over Six Years at Snoqualmie Pass in the Cascade Range, Washington State. Arctic, Antarctic and Alpine Research 37: 411-415.

https://www.jstor.org/stable/4095859?seq=1\#metadata_inf o_tab_contents

Armstrong RA (2006) Seasonal growth of the crustose lichen Rhizocarpon geographicum (L.) DC. in south Gwynedd, Wales. Symbiosis 41: 97-102.

Armstrong RA (2015) The influence of environmental factors on the growth of lichens in the field. In: Upreti DK, Divakar PK, Shukla V, Bajpal R (eds.), Recent Advances in Lichenology. India: Springer International Publishing; p. 1-18. https://doi.org/10.1007/978-81-322-2181-4

Armstrong RA (2016) Invited review: Lichenometric dating (lichenometry) and the biology of the lichen genus Rhizocarpon: challenges and future directions. Geogr Ann A. 98: $183-206$ https://doi.org/10.1111/geoa.12130

Armstrong RA, Bradwell T (2001) Variation in prothallus width and the growth of the lichen Rhizocarpon geographicum (L.) DC. Symbiosis 30: $317-328$.

Armstrong RA, Bradwell T (2010a) The use of lichen growth rings in lichenometry: Some preliminary findings. Geogr Ann A 92A: 141-147.

https://doi.org/10.1111/j.1468-0459.2010.00383.x

Armstrong RA, Bradwell T (2010b) Growth of crustose lichens: a review. Geogr Ann A. 92A: 3-17. https://doi.org/10.1111/j.1468-0459.2010.00374.x

Armstrong RA, Bradwell T (2015) 'Growth rings' in crustose lichens: Comparison with directly measured growth rates and implications for lichenometry. Quaternary Geochronology 28: 88-95.

https://doi.org/10.1016/j.quageo.2015.04.003

Armstrong RA, Smith SN (1987) Development and growth of the lichen Rhizocarpon geographicum. Symbiosis 3: 287-300. comments and Maria Król (Tatra National Park) for help in the field research.

provided you give appropriate credit to the original author(s) and the source, provide a link to the Creative Commons license, and indicate if changes were made.
Benedict JB (1991) Experiments on lichen growth II. Effects of a seasonal snow cover. Arctic and Alpine Research 23(2): 189199.

https://doi.org/10.1080/00040851.1991.12002836

Benedict JB (2008) Experiments on lichen growth. III. The shape of the age-size curve. Arctic, Antarctic and Alpine Research 40: 15-26.

https://doi.org/10.1657/1523-0430(o6030)[BENEDICT]2.0.CO;2

Benedict JB (2009) A Review of Lichenometric Dating and Its Applications to Archaeology. American Antiquity 74(1): 143172.

https://doi.org/10.2307/25470542

Beschel RE (1961) Dating rock surfaces by growth and its application to glaciology and physiography (lichenometry). Geology of the Arctic.

Beschel RE (1973) Lichens as measure of the age of recent moraines. Arctic and Alpine Research 5(4): 303-309.

Błażejczyk K, Baranowski J, Błażejczyk A, Szmyd J (2013) Climate and bioclimate of Hala Gąsienicowa. In: Raczkowska Z, Kotarba A (eds)Sucha Woda Valley in the Tatra Mountains. The environment and its contemporary changes. Prace Geograficzne 239: 67-95.

Bradwell T (2009) Lichenometric dating: A commentary, in the light of some recent statistical studies. Geogr Ann A. 91(2): 61-69.

https://doi.org/10.1111/j.1468-0459.2009.00354.x

Bradwell $\mathrm{T}$ (2010) Studies on the growth of Rhizocarpon geographicum in NW Scotland, and some implications for lichenometry. Geogr Ann A. 92(1): 41-52. https://doi.org/10.1111/j.1468-0459.2010.00376.x

Calkin PE, Kaufman S, Przybyl BJ, et al. (1998) Glacier regimes, periglacial landforms, and Holocene climate change in the Kigluaik Mountains, Steward Peninsula, Alaska, USA. Arctic, Antarctic and Alpine Research 30: 154-165.

Decaulne A, Sæmundsson T, and Pétursson O (2005) Debris flows triggered by rapid snowmelt: a case study in the Glei. arh- jalli area, north western Iceland. Geogr Ann A 87(4): 487-500. https://doi.org/10.1111/j.0435-3676.2005.00273.x

Evans DJA, Archer S (1999) A comparison of the lichenometric and Schmidt hammer dating techniques based on data from the proglacial areas of some Icelandic glaciers. Quaternary Science Reviews 18: 13-41.

https://doi.org/10.1016/So277-3791(98)ooo98-5

Forman SL, Marín L, Van der Veen C, et al. (2007) Little Ice Age and neoglacial landforms at the Inland Ice margin, Isunguata Sermia, Kangerlussuaq, west Greenland. Boreas 36: 341-351. https://doi.org/10.1080/00173130601173301

Gupta V, Vaideswaran SC, Dobhal DP (2014) Colonization delay of Rhizocarpon geographicum: Study from the Gangotri glacier, northwestern Himalaya 84(3): 335-340. 
https://doi.org/10.1007/s12594-014-0137-8

Hansen ES (2010) A review of lichen growth and applied lichenometry in southwest and southeast Greenland. Geogr Ann A. 92(1): 65-79.

https://doi.org/10.1111/j.1468-0459.2010.00378.x

Hansen ES (2008) The application of lichenometry in dating of glacier deposits. Geografisk Tidsskrift-Danish Journal of Geography 108(1): 143-151.

https://doi.org/10.1080/00167223.2008.10649580

Hess M (1965) Vertical climatic belts in the Polish Western Carpathians. Zeszyty Naukukowe UJ, Prace Geograficzne 11: 1-267.

Innes JL (1982) Lichenometric use of an aggregated Rhizocarpon species. Boreas 11(1): 53-57.

Innes JL (1983) Size frequency distributions as a lichenometric technique: an assessment. Arctic and Alpine Research 15(3): 285-294.

Innes JL (1984) The optimal sample-size in lichenometric studies. Arctic and Alpine Research 16(2): 233-244.

Innes JL (1985a) A standard Rhizocarpon nomenclature for lichenometry. Boreas 14(1): 83-85.

https://doi.org/10.1111/j.1502-3885.1985.tboo890.x

Innes JL (1985b) Lichenometry. Progress in Physical Geography

https://doi.org/10.1177/030913338500900202

Innes JL (1988) The use of lichens in dating. In: Galun M (ed.), Handbook of Lichenology III. Florida: CRC Press, Boca Raton. pp 75-91.

Jonasson C, Kot M, Kotarba A (1991) Lichenometrical studies and dating of debris flow deposits in the High Tatra Mountains, Poland. Geogr Ann A. 73(3): 141-146. https://doi.org/10.108o/04353676.1991.11880339

Karlén W (1973) Holocene Glacier and Climatic Variations, Kebnekaise Mountains, Swedish Lapland. Geogr Ann 55(1): 29-63. https://doi.org/10.108o/04353676.1973.11879879

Kędzia S (2013) Problems and possibilities of lichenometric dating in Polish mountains. Geographia Polonica 86(4): 363374. https://doi.org/10.7163/GPol.2013.29

Kędzia S (2015a) The occurrence of glaciers in the Polish Tatra Mountains during the Little Ice Age. Zeitschrift für Geomorphologie 59(2): 229-241.

https://doi.org/10.1127/zfg/2014/0150

Kędzia S (2015b) Lichenometric curves for the Polish part of the Karkonosze and Tatra Mountains established with a new method. Zeitschrift für Geomorphologie 59(1): 103-118. https://doi.org/10.1127/0372-8854/2014/0141

Kędzia S, Parzóch K (2013) The activity of debris flows in the Łomniczka Cirque in the Light of lichenometric dating. Opera Corcontica 5o/S: 75-80.

Kędzia S, Parzóch K (2016) The activity of debris flows in the Polish part of the Karkonosze Mountains in the light of lichenometric measurements. Przegląd Geograficzny 88(3): 401-416. https://doi.org/10.7163/PrzG.2016.3.0
Koňcek M, Orlicz M (1974) Tepłotnè pomery. In: Konček M (ed.),The climate of the Tatra Mountains. Bratysława: Wydawnictwo Słowackiej Akademii Nauk. pp 89-179.

Kotarba A (1988) Lichenometry and its application in research geomorphology in the Tatras. Wszechświat 89(1): 13-15.

Kotarba A (1989) On the age of debris slops in the Tatra Mountains. Studia Geomorphologica Carpatho-Balcanica 23: 139-152.

Kotarba A (1991) On the ages and magnitude of debris flows in the Polish Tatra Mountains. Bulletin of the Polish Academy of Science 39(2): 129-135.

Kotarba A (2001) Lichenometric determination of the age of the form high mountain relief. Prace Geograficzne IGiPZ PAN 179; 197-208.

Kotarba A (2004) Geomorphological events in the High Tatra Mountains during the Little Ice Age. In: Kotarba A (ed) The role of the Little Ice Age in transforming the natural environment of the Tatra Mountains. In: Kotarba A (ed) Prace Geograficzne IGiPZ PAN 197: 9-55.

Larocque SJ, Smith DJ (2004) Calibrated Rhizocarpon spp. growth curve for the Mount Waddington Area, British Columbia Coast Mountains, Canada. Arctic, Antarctic, and Alpine Research 36(4): 407-418.

Matthews JA (1974) Families of lichenometric dating curves from the Storbreen gletschervorfeld, Jotunheimen, Norway. Norsk Geografisk Tidsskrift - Norwegian Journal of Geography 28(4): 215-235.

Osborn G, McCarthy D, Labrie A, Burke R (2015) Lichenometric dating: science or pseudo-science? Quaternary Research 83: 1-12. https://doi.org/10.1016/j.yqres.2014.09.006

Pech P, Jomelli V, Baumgart-Kotarba M, et al. (2003) A lichenometric growth curve in the French Alps: Ailefroide and Venon valleys; Massif des Ecrins. Geodinamica Acta 16: 187193.

Solomina O, Calkin PE (2003) Lichenometry as Applied to Moraines in Alaska, U.S.A., and Kamchatka, Russia. Arctic, Antarctic, and Alpine Research 35(2): 129-143.

Solomina O, Ivanov MN, Bradwell T (2010) Lichenometric studies on moraines in the Polar Urals. Geogr Ann A. 92(1): 81-99.

Topham PB (1976) Colonisation, growth, succession, and competition. In: Seaward MRD (ed.), Lichen Ecology. London and New York: Academic Press. pp 31-68.

Trenbirth HE, Matthews JA (2010) Lichen growth rates on glacier forelands in southern Norway: preliminary results from a 25-year monitoring programme. Geogr Ann A. 92(1): 19-39. https://doi.org/10.1111/j.1468-0459.2010.00375.x

Webber PJ, Andrews JT (1973) Lichenometry: a commentary. Arctic and Alpine Research 5(4): 295-302.

Winchester V, Chaujar RK (2002) Lichenometric dating of slope movements, Nant Ffrancon, North Wales. Geomorphology 47: 61-74. 